\title{
High temperature tolerance in chickpea and its implications for plant improvement
}

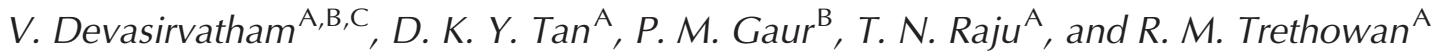 \\ APlant Breeding Institute, Faculty of Agriculture and Environment, University of Sydney, Cobbitty, \\ NSW 2570, Australia. \\ ${ }^{B}$ International Crops Research Institute for Semi-Arid Tropics, Patancheru 502324, Andhra Pradesh, India. \\ ${ }^{\mathrm{C}}$ Corresponding author. Email: viola.devasirvatham@sydney.edu.au
}

\begin{abstract}
Chickpea (Cicer arietinum L.) is an important food legume and heat stress affects chickpea ontogeny over a range of environments. Generally, chickpea adapts to high temperatures through an escape mechanism. However, heat stress during reproductive development can cause significant yield loss. The most important effects on the reproductive phase that affect pod set, seed set and yield are: (1) flowering time, (2) asynchrony of male and female floral organ development, and (3) impairment of male and female floral organs. While this review emphasises the importance of high temperatures $>30^{\circ} \mathrm{C}$, the temperature range of $32-35^{\circ} \mathrm{C}$ during flowering also produces distinct effects on grain yield. Recent field screening at ICRISAT have identified several heat-tolerant germplasm, which can be used in breeding programs for improving heat tolerance in chickpea. Research on the impact of heat stress in chickpea is not extensive. This review describes the status of chickpea production, the effects of high temperature on chickpea, and the opportunities for genetic improvement of chickpea tolerance to high temperatures.
\end{abstract}

Additional keywords: genetic variation, legumes, pollen, semi-arid tropics, tolerance.

Received 19 August 2011, accepted 7 June 2012, published online 9 July 2012

\section{Introduction}

Chickpea is a major grain legume used for food from ancient days. It is one of the essential semi-arid tropical legume crops. Chickpea is either grown during the post-rainy season on stored soil moisture (south Asia and spring-sown Mediterranean) or as a Mediterranean winter crop on in-season rainfall; in both instances the crop is exposed to terminal drought which is accompanied by rising temperatures. The south Asian crop may also experience high temperatures in the seedling phase if planted early (Berger and Turner 2007). Chickpea productivity is constrained by several abiotic stresses (Singh et al. 1994; Gaur et al. 2007) and temperature is one of the most important determinants of crop growth over a range of environments (Summerfield et al. 1990) and may limit chickpea yield (Basu et al. 2009).

The effects of heat stress during the vegetative and reproductive growth stages using agronomic, phenological, morphological and physiological assessment has been studied in various crops such as wheat (Sharma et al. 2005), rice (Weerakoon et al. 2008) and cotton (Cottee et al. 2010) while only limited research has been conducted in chickpea (Wang et al. 2006). The detrimental effects of high temperature on various growth and reproductive stages are difficult to assess when growing conditions are favourable in the short-term (few days) as the plant continues vegetative growth but sets fewer pods because of indeterminate plant type and plasticity (Liu et al. 2003). The relatively narrow genetic base of chickpea is another reason why high temperature has such a detrimental effect on growth and reproductive physiology (Abbo et al. 2003a). For these reasons chickpea tends to be sensitive to high temperature during the growth and reproductive stages. In general, the cool season food legumes (peas, lentil, chickpea and faba bean) are more sensitive to heat than warm season legumes (cowpea, soybean, groundnut, pigeonpea, and mung bean). Among cool season legumes, chickpea is less sensitive to high temperature (Wery et al. 1993; McDonald and Paulsen 1997). Although chickpea is exposed to warm temperatures $\left(>30^{\circ} \mathrm{C}\right)$ in certain regions, limited yield loss was found at $30^{\circ} \mathrm{C}$, which is higher than other cool season legumes such as field peas, faba bean and lentil (Summerfield et al. 1984; Erskine et al. 1994; McDonald and Paulsen 1997; Patrick and Stoddard 2010). Therefore, a base level of heat tolerance is found in chickpea. However, there is no clear evidence to show the mechanism of heat tolerance. This review outlines the occurrence of high temperature stress, the state of chickpea production, the effects of high temperature on growth and physiology of chickpea, and explores strategies to improve chickpea breeding for heat tolerance.

\section{State of chickpea production}

Climates favourable for chickpea production fall into two general groupings; Mediterranean and summer-dominant 
rainfall semi-arid subtropical climates (Berger and Turner 2007). Chickpea production is also grouped into three regions globally: West Asia and North Africa (WANA), the Indian subcontinent region and recently emerged regions. The details of these regions, their climate and relative intensity of the principal stresses are discussed by Berger and Turner (2007). Chickpea is extensively cultivated in the Mediterranean climate regions of northern Pakistan, Iran, Iraq, Turkey, southern and south-western Australia and the Mediterranean basin. In these areas, chickpea is widely sown in winter at a maximum air temperature of $10^{\circ} \mathrm{C}$ (Berger 2007) and high temperatures occasionally occur during reproductive development in the spring (Iliadis 1990).

In the Indian subcontinent region and recently emerged regions (e.g. eastern, northern and southern Australia), the crop experiences cool $\left(5-10^{\circ} \mathrm{C}\right)$ and frosty nights $\left(0\right.$ to $\left.-1^{\circ} \mathrm{C}\right)$ in the early vegetative stage and warm $\left(20-27^{\circ} \mathrm{C}\right)$ to hot $\left(>30^{\circ} \mathrm{C}\right)$ air temperature during the day over the reproductive phase (Summerfield et al. 1984, 1990; Berger and Turner 2007). During the last two decades, south Indian and eastern Australian late-sown chickpea has been exposed to heat stress in the growing season, mainly in reproductive phase. In south India, if the rainy season (kharif) is extended, then the chickpea sowing in the rabi season will be delayed (Ali 2004). This delay exposes the crop to high temperatures during the reproductive stage. Ninety percent of Australian chickpea is produced in Tamworth. In Australia, particularly in northern NSW and depending on the climatic conditions, sowing can be delayed until the last week of June to reduce the incidence of Ascochyta blight (Moore and Knights 2009). However, late-sown crops may experience high temperatures during the reproductive phase. Berger and Turner (2007) and Berger et al. (2011) described the global chickpea distribution based on climate analysis and current production trends. The climate analysis showed that the current chickpea-growing area is under threat from increasing temperature and production may extend to cooler regions.

\section{The nature of heat stress and plant response}

High temperature often occurs in combination with high solar irradiance, drought, and strong wind, all of which can aggravate plant injury even in well-watered plants (Hall 1992). Heat stress is a function of plant genotype, high temperature, water status and soil type. The occurrence and severity of heat stress varies in different regions from year to year. Depending on timing, duration and interaction, observed heat stress can be grouped into chronic and acute, each of which involve different coping mechanisms, adaptation strategies and ultimately, breeding techniques (Blum 1988; Wery et al. 1993). Chronic heat stress occurs at any stage of crop growth and generally results in substantial yield loss and even crop failure. Acute heat stress of relatively short duration can occur at any stage of crop growth, often leading to lower yield. Acute heat stress is more prevalent than chronic heat stress in the spring-sown chickpea regions of WANA (e.g. Turkey) and the Indian subcontinent region. In the spring crop, the mean seed yield of $1627 \mathrm{~kg} \mathrm{ha}^{-1}$ decreased compared with the autumn crop due to seasonal temperature fluctuation $\left(26-38^{\circ} \mathrm{C}\right)$ during the reproductive stage (Ozdemir and Karadavut 2003). In north India, chickpea grain yield decreased by $53 \mathrm{~kg} \mathrm{ha}^{-1}$ in Uttar Pradesh and $301 \mathrm{~kg} \mathrm{ha}^{-1}$ in Haryana per $1^{\circ} \mathrm{C}$ increase in seasonal temperature (Kalra et al. 2008). Pod development is clearly impaired at above optimum $\left(>30^{\circ} \mathrm{C}\right)$ temperatures (Summerfield et al. 1984). Nevertheless, different genotypes have a range of tolerance or resistance mechanisms that help them cope.

\section{Genotypic variability for heat tolerance}

During the Greek and Roman period, chickpea was grown as a summer crop (sown in March-April and harvested in June-July) (Kumar and Abbo 2001). In the Mediterranean and near-eastern gene pools, the wild Cicer reticulatum germinates after autumn rain and the crop matures in spring. During the spring the crop is exposed to rising temperature which influences the flowering period, accelerates maturity and may limit yield. However, the shift of chickpea sowing from autumn to spring occurred early in the crop's history (Abbo et al. 2003b) and was driven by high fungal disease (Ascochyta blight) incidence in the autumn-sown crop (Kumar and Abbo 2001). This shift of season has likely caused a genetic bottleneck which narrowed the genetic diversity (Abbo et al. 2003a) and most probably genetic variation for heat tolerance. Therefore, the origin and diversity of genetic resources must be considered when screening germplasm for heat tolerance if the plant breeder is to improve the temperature tolerance of modern chickpea in the target environments.

A decade ago, the heat-tolerant genotypes ICCV 88512 and ICCV 88513 were identified from among 25 genotypes (Dua 2001). Recently, a reference collection of 280 diverse chickpea germplasm was screened in the field for heat tolerance in two locations (Patancheru and Kanpur) in India during the post-rainy season (optimum) and summer season (late heat). Based on a Heat Tolerance Index (HTI) ( $\geq 1.00)$, ICC 3362, ICC 6874 and ICC 12155 were identified as heattolerant lines. ICC 16374, ICC 4567 and ICC 10685 were classified as heat-sensitive lines based on low HTI (negative values) (Krishnamurthy et al. 2011). Upadhyaya et al. (2011) identified ICC 14346 as a heat-tolerant genotype among 35 early maturing germplasm under ideal crop management (irrigation, nitrogen application) conditions in field screening at Patancheru based on yield $\left(\mathrm{kg} \mathrm{ha}^{-1}\right)$. At present, genotypic diversity of chickpea global germplasm collections and chickpea production environments, particularly those affected by high temperature have not been amply studied. The heat tolerance of chickpea is likely to be multi-genic and the components of heat tolerance are probably controlled by different sets of genes (Upadhyaya et al. 2011).

\section{Plant responses to heat}

Effect of heat stress on crop establishment (germination and crop development)

Heat stress at sowing directly affects crop germination and crop establishment. Chickpea seed germination decreases at supra-optimum temperatures (Singh and Dhaliwal 1972; Ellis et al. 1986). Ellis et al. (1986) indicated that the optimal temperature for germination is $10-15^{\circ} \mathrm{C}$ and noted that high germination temperatures are considered to be $22-35^{\circ} \mathrm{C}$. Covell et al. (1986) showed that germination was faster at 
higher temperatures between 31.8 and $33^{\circ} \mathrm{C}$. However, at high temperatures the mobilisation of cotyledon reserves and embryo growth are adversely affected. While chickpea showed genotypic variation in the rate of germination under various temperatures (Ellis et al. 1986), the germination percentage of chickpea was zero when temperature ranged between 45 and $48^{\circ} \mathrm{C}$ (Singh and Dhaliwal 1972). High mean maximum temperature and low relative humidity can have a marked influence on seedlings (Saxena 1987). Low photosynthetic rates and high transpiration rates occur during high temperature stress and tend to reduce plant establishment in chickpea (Singh and Dhaliwal 1972). Recent climate data from field experiments in south India (Patancheru $-18^{\circ} \mathrm{N}, 78^{\circ} \mathrm{E}$ ) during sowing time after the rainy season (last week of October) showed a temperature range of $28-31^{\circ} \mathrm{C}$ (Upadhyaya et al. 2011). Sowing temperature is an important determinant of yield, and will become a significant constraint should predicted climate change lead to higher future sowing temperatures.

Though early phenology was mentioned in the heat escape mechanism section, the importance of early phenology in chickpea breeding for heat tolerance will be discussed in greater detail in this section. Higher temperature and photoperiod can modify plant phenology (e.g. opening of first flower), particularly if crops are exposed to warming temperatures and long days in summer (van der Maesen 1972; Summerfield et al. 1984). An understanding of these effects and their interactions with genotype are needed in field screening under stress. Breeders generally use days to first flowering as an indicator of crop duration (Anbessa et al. 2006). The photoperiod-sensitive genotype (Chafa) produced flowers in 25 days under optimum temperature $\left(26^{\circ} \mathrm{C}\right)$ and 15-h photoperiod compared with 52 days in the late flowering genotypes ( $\mathrm{K}$ 850, G 130) (ICRISAT 1979). The flowering model studies of Summerfield et al. (1985) indicated that the rate of progress towards flowering was a linear function of mean temperature and there was no interaction between photoperiod and mean temperature. However, the linear development of the plant through to flowering only occurs within a defined range above which the rate of development declines. These critical temperatures vary among genotypes with tolerant lines having higher optimum temperatures compared with sensitive genotypes.

\section{Effect of heat stress on reproductive development and yield}

Chickpea has small flowers and the stamens are diadelphous $(9+1$ anthers). Self pollination takes place before the flower opens and pods form within 5-6 days (Singh 1997). Heat stress during the reproductive phase in legumes is generally allied with lack of pollination, abscission of flower buds, flowers and pods with substantial yield loss (Nakano et al. 1997, 1998). Hot $\left(>30^{\circ} \mathrm{C}\right)$ and dry atmospheric conditions lead to profligate loss of flower buds and open flowers in chickpea (Sinha 1977).

High temperature after flower opening decreases chickpea seed yield by reducing the number of seeds per plant and weight per seed (Wang et al. 2006). In chickpea, Summerfield et al. (1984) suggested that the longer the exposure during reproductive development to a high day temperature of $35^{\circ} \mathrm{C}$, the lower the yield. Most chickpea genotypes do not set pods when temperatures reach $>35^{\circ} \mathrm{C}$ (Basu et al. 2009). However, there is considerable variation among genotypes for response to high temperature. The period of anthesis and seed set are clearly critical stages for exposure to heat stress (Gross and Kigel 1994). Nayyar et al. (2005) suggested that the development of male (pollen, anthers) and female (stigma-style, ovary) parts are the most sensitive organs to abiotic stress in reproductive biology. Therefore, pollen viability, stigma receptivity and ovule viability are useful indicators of sensitivity to abiotic stress (Nayyar et al. 2005). However, the effect of stress on either male or female organs depends upon the stage of sporogenesis (micro or mega). Due to heat stress, meiosis and pollen development are the most affected part in micro-sporogenesis. Megaspore formation in the ovule and fertilisation are the most important events in mega-sporogenesis under high temperature stress (Gross and Kigel 1994).

High temperature effects on pre-anthesis are related to anther development, pollen sterility and pollen production. The study of pollen may help to predict genetic variation among genotypes for reproductive phase heat tolerance. Pollen sterility is one of the key factors limiting legume yield under high temperature (Porch and Jahn 2001). Eight stages of chickpea pollen development, from pollen mother cell development to mature pollen can be distinguished (Fig. 1). Two of the stages, microspore mother cell meiosis and mature microspores at anthesis, appear to be detrimentally affected by

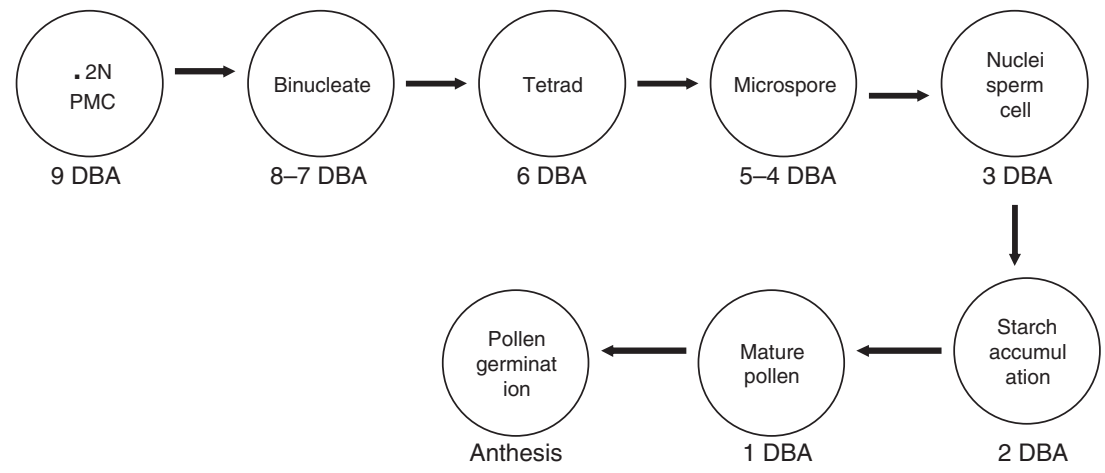

Fig. 1. Sequences of chickpea pollen development. 
high temperature (Iwahori 1965; Ahmed et al. 1992). The microspore mother cell meiosis, particularly early meiosis I, II is also sensitive to high temperature (Iwahori 1965). Ahmed et al. (1992) reported that tapetal cells (meiosis II) did not become binucleate and the locular cavity was less developed in anthers under high temperatures $\left(33^{\circ} \mathrm{C}\right.$ day $/ 30^{\circ} \mathrm{C}$ night $)$ resulting in premature pollen development. Such information is lacking in chickpea at meiosis stage. Most of the pollen studies in chickpea have focussed on cold tolerance (Srinivasan et al. 1999; Clarke et al. 2004) and the meiosis stage [9 days to 5-6 days before anthesis (DBA)] of chickpea was found to be sensitive to cold $\left(<3^{\circ} \mathrm{C}\right)$ (Clarke and Siddique 2004).

Reduced pollen viability is common in legumes during preanthesis. In chickpea, $80-90 \%$ pollen germination occurs in the range $7-25^{\circ} \mathrm{C}$ (assessed after $4 \mathrm{~h}$ incubation in vitro). During germination pollen hydration is inhibited by low temperature (Clarke and Siddique 2004). In vitro pollen germination after $60 \mathrm{~min}$ incubation was higher $(61 \%)$ at $25^{\circ} \mathrm{C}$ in chickpea compared with $45^{\circ} \mathrm{C}$ (33\%) (Jaiwal and Mehta 1983). Therefore, both high and low temperatures reduce pollen germination. Pollen abnormalities were observed in cowpea at $33 / 30^{\circ} \mathrm{C}$ when plants were exposed to heat $3 \mathrm{DBA}$ (Ahmed et al. 1992). Anther indehiscence in bean occurred at $32 / 27^{\circ} \mathrm{C}$ when subjected to heat stress during the period 9-13 DBA (Gross and Kigel 1994; Porch and Jahn 2001). Pollen production was reduced $\sim 30-50 \%$ at $38 / 300^{\circ} \mathrm{C}$ compared with $30 / 22^{\circ} \mathrm{C}$ in soybean (Koti et al. 2005). Therefore, pre-anthesis flower abortion is caused by male sterility resulting from abnormal pollen development and anther indehiscence (Warrag and Hall 1984). In chickpea there is genotypic variability for high temperature sensitivity. At $35 / 20^{\circ} \mathrm{C}$ day/night exposure for $24 \mathrm{~h}$ before anthesis, the chickpea genotype ICC 5912 became sterile, while pollen from the genotype ICCV 92944 was fertile (Devasirvatham et al. 2010) (Fig. 2).

High temperature effects post-anthesis are associated with loss of stigma receptivity (Kakani et al. 2002), poor pollen germination, pollen tube growth on the stigma (Talwar and Yanagihara 1999) and failure of pollen fertilisation and ovule formation (Ormrod et al. 1967). Heat stress sometimes has a combined effect on male and female parts, thus creating asynchrony between male and female organs (Zinn et al. 2010). There is a lack of information about asynchrony in chickpea under heat stress. Nevertheless, progress has been made in chickpea reproductive biology under cold stress. The stigma receptivity is reported to be low at low temperatures $\left(12 / 7^{\circ} \mathrm{C}\right)$ in chickpea (Nayyar et al. 2005). At $12 / 7^{\circ} \mathrm{C}$, decline in pollen germination and pollen tube growth on the stigma may be associated with stigma receptivity (Clarke and Siddique 2004). This might occur due to low amounts of exudates on the stigma (Nayyar et al. 2005). Lack of pollen germination and tube growth in the style was found in the heatsensitive genotype ICC 5912 at $35 / 20^{\circ} \mathrm{C}$ due to sterile pollen (Devasirvatham et al. 2010). In this study, stigma receptivity was not affected by high temperature stress. However, the observed reduction in pollen germination at high temperature on the stigma is not clear. Therefore, it is essential that the effect of heat stress on pollen function (pollen germination and tube growth) and stigma receptivity of genotypes in the field be studied.

Pre-anthesis heat stress resulted in flower abortion indicating that this stress limits pod formation. In addition, the number of days of exposure to high post-anthesis temperatures is important in legumes. The timing of pre- and post-anthesis heat stress was studied in cowpea (Hall 1992) and groundnut (Vara Prasad et al. 2001). A combination of pre- and postflowering stress reduced pod set in bean at $34 / 29^{\circ} \mathrm{C}$ (Agtunong et al. 1992). The maximum sensitivity to hot day temperatures $\left(38^{\circ} \mathrm{C}\right)$ in groundnut occurred anywhere between 6 days before and 15 days after flowering which can reduce the fruit set, i.e. the proportion of flowers producing pegs or pods (Vara Prasad et al. 1999, 2001). These examples indicate that the period of anthesis (pre-anthesis; anthesis and post-anthesis) and number of days of exposure to heat during flowering play an essential role in the development of reproductive organs, i.e. pods.

Generally, the responses of plants to high temperature are assessed under high day temperature. However, high night temperature might also play a significant role in legumes and can influence seed set. Anthers failed to dehisce and pod
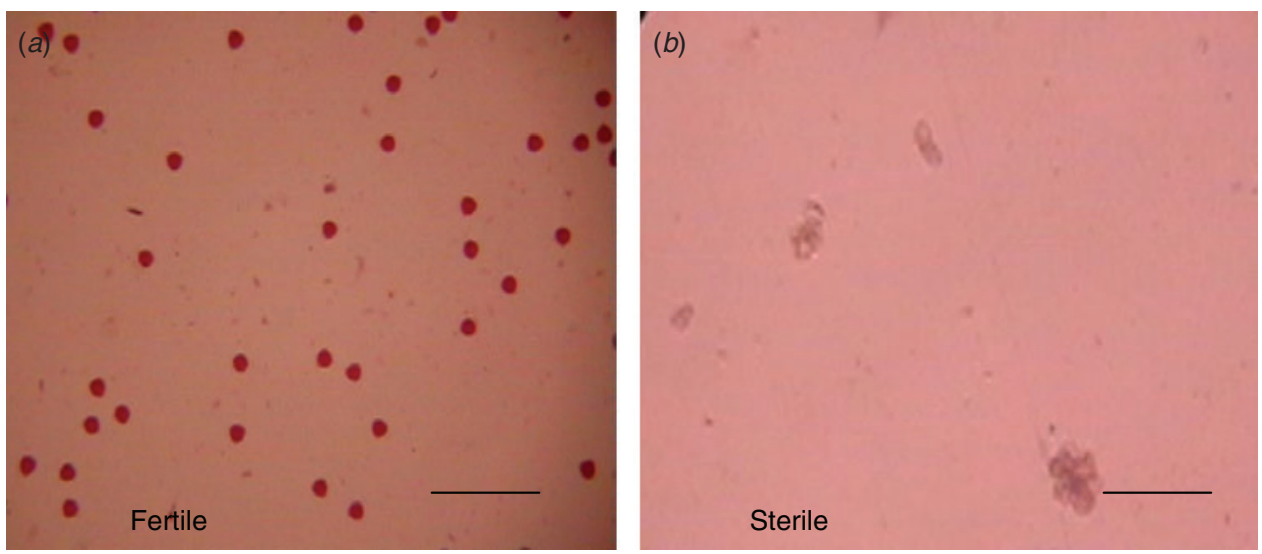

Fig. 2. Fertile and sterile pollen of chickpea at $35 / 20^{\circ} \mathrm{C}$ (pollen grains stained with $2 \%$ acetocarmine). (a) Fertile pollen of ICCV 92944 (picked up stain); (b) sterile pollen of ICC 5912 (no stain) (Devasirvatham et al. 2010) (bars $=10 \mu \mathrm{m}$ ). 
development was affected by a high night temperature of $27^{\circ} \mathrm{C}$ in bean (Konsens et al. 1991). In cowpea, high night temperature $\left(33 / 30^{\circ} \mathrm{C}\right)$ increased the occurrence of small and shrunken pollen leading to zero pod set compared with low night temperature $\left(33 / 20^{\circ} \mathrm{C}\right)$ (Ahmed et al. 1992). Therefore diurnal temperatures play an important role in legume male reproductive organs (Ahmed et al. 1992). However, little is known about these effects in chickpea.

Seed development in legumes is a function of the rate and duration of embryo growth, which is in turn influenced by abiotic stress that may lead to embryo abortion (Warrag and Hall 1983), or small endosperms (Davies et al. 1999). Finally endosperm filling in the seed is affected by high temperature resulting in small or wrinkled seeds (Egli et al. 2005). The probable reason for small endosperm or smaller seed size after post-anthesis heat stress is that the remobilisation of photosynthates to the grain is reduced. A large proportion of carbohydrate is generally utilised to fill the grain in legumes (Davies et al. 1999), thus influencing seed weight and number. Under heat stress seeds are not fully developed in sensitive genotypes at agronomic maturity (Sivakumar and Singh 1987). More research is needed to address the remobilisation of the photosynthates to chickpea seeds under heat stress.

Seed quality (uniformity of seed size, shape, colour and texture of the seed coat) is important for grain marketing and is subjected to genotypic $\times$ environmental effects that seem to be related to abiotic stress, particularly in kabuli chickpea (Sivakumar and Singh 1987; Leport et al. 1999). While heat stress is expected to play a role here, its effects have not been well studied.

In summary, available evidence indicates that chickpea crop establishment (seedling growth) has a lower supraoptimal temperature $\left(20-24^{\circ} \mathrm{C}\right)$ than pollen germination or pollen tube growth $\left(25^{\circ} \mathrm{C}\right)$ (Table 1). However, high temperature frequently occurs during the reproductive stage in chickpea production areas. Heat stress has important effects on the reproductive period that influence time to pod set, seed set and yield including: (1) flowering time, (2) asynchrony of male and female organ development, and (3) impairment of male and female organs (Craufurd and Wheeler 2009; Zinn et al. 2010). Therefore, improved understanding of chickpea response to heat stress (both day and night temperatures) combined with the timing and duration (short or acute/long or chronic) of heat stress is important for chickpea breeding.

\section{Effect of heat stress on physiology}

Photosynthetic rate and chlorophyll content are important physiological parameters in plants. Heat stress directly affects photosynthesis including photosystem II in chickpea (Srinivasan et al. 1996). The rate of photosynthesis has a negative linear relationship with temperature (Grace 1988). Peak photosynthetic rate was observed at suboptimal temperatures $\left(22^{\circ} \mathrm{C}\right)$ in chickpea under controlled environments (Singh et al. 1982). At Hissar in north India, the net photosynthetic rate at $25^{\circ} \mathrm{C}$ was linearly related to photon flux density and reduced at $\geq 28^{\circ} \mathrm{C}$ (Singh et al. 1987). Singh et al. (1987) also reported that transpiration efficiency (photosynthesis/transpiration) of chickpea decreases with increasing temperature. Photosynthetic rates are higher during $50 \%$ flowering to pod formation than the vegetative stage in chickpea. Photosynthetic duration is controlled by the requirement of assimilates in the growing organs (e.g. leaves) and the reproductive organs (e.g. pods) (Singh et al. 1987) and also by the environment.

Membrane stability of leaf tissue can be used as another physiological indicator of heat stress, and is determined by electrolyte leakage measured as electrical conductivity (Stoddard et al. 2006). Genotypic variation for heat tolerance in chickpea was evaluated during vegetative, flowering and pod-filling stages by testing cell membrane thermostability (using electrolyte leakage). The chickpea lines Annigeri, ILC 482 and ICCV 10 were more thermostable at $45^{\circ} \mathrm{C}$ than $\mathrm{K} 850$ and injury decreased with crop development (Srinivasan et al. 1996). However, there is no evidence of a relationship between cellular integrity under heat stress and grain yield. Tongden et al. (2006) used cell membrane stability as a screening technique at the seedling stage of chickpea to identify heat-tolerant and sensitive cultivars.

The plant is unlikely to show any significant yield difference due to short duration (acute) heat stress and distinguishing genotypes may be difficult. Under such situations, testing

Table 1. Summary of findings on the effect of high temperature on germination, growth and development and flowering of chickpea

\begin{tabular}{|c|c|c|c|}
\hline Crop stage & $\begin{array}{l}\text { Optimum } \\
\text { temperature }\end{array}$ & $\begin{array}{c}\text { Detrimental } \\
\text { high temperature }\end{array}$ & References \\
\hline \multicolumn{4}{|c|}{ Germination } \\
\hline Soil temperature & $15-34^{\circ} \mathrm{C}$ & $\geq 35^{\circ} \mathrm{C}$ & Singh and Dhaliwal (1972) \\
\hline Air temperature & $31.8-33^{\circ} \mathrm{C}$ & $\geq 35^{\circ} \mathrm{C}$ & Covell et al. (1986) \\
\hline \multicolumn{4}{|c|}{ Growth and development } \\
\hline Seedling growth & $20-24^{\circ} \mathrm{C}$ & $\geq 28^{\circ} \mathrm{C}$ & Sivaprasad and Sundrasarma (1987) \\
\hline Leaf growth & $10-25^{\circ} \mathrm{C}$ & $\geq 27^{\circ} \mathrm{C}$ & Khanna-Chopra and Sinha (1987) \\
\hline Early growth & $20-26^{\circ} \mathrm{C}$ & $\geq 27^{\circ} \mathrm{C}$ & van der Maesen (1972) \\
\hline \multicolumn{4}{|c|}{ Flowering } \\
\hline In vitro pollen germination & $25^{\circ} \mathrm{C}$ & $35^{\circ} \mathrm{C}$ & Jaiwal and Mehta (1983) \\
\hline In vitro pollen tube growth & $25^{\circ} \mathrm{C}$ & $45^{\circ} \mathrm{C}$ & Jaiwal and Mehta (1983) \\
\hline Flowering and pod development & $20-26^{\circ} \mathrm{C}$ & $\geq 30^{\circ} \mathrm{C}$ & Summerfield et al. (1980) \\
\hline
\end{tabular}


membrane stability and photosynthesis may be more suitable screening techniques if they can be linked with injury to tissue or physiological process.

The rate of assimilate partitioning and leaf senescence are important physiological responses that influence pod set and yield. Carbohydrates (accumulated at the time of photosynthesis) supplied to the reproductive organs (e.g. flowers and pods) directly influence grain filling (Hendrix 2001). The rapid growth and development of reproductive organs arises through partitioning of a large proportion of the net-accumulated biomass from leaves under heat stress (Evans 1993). However, there are limited physiological studies on chickpea heat tolerance and the interaction between germplasm and environments.

In general, the success of heat screening physiological techniques depends on the frequency of heat stress in the field and the relevance of managed screening techniques to the target environment (Wery et al. 1994). Limited screening techniques have been developed for heat tolerance in chickpea (Singh et al. 1994) because significant genotypic $\times$ environmental interaction and differences in phenology make screening difficult (Wery et al. 1994). Hence, the improvement of heat tolerance in chickpea is dependent upon access to reliable and accurate phenotyping procedures.

\section{Effect of heat stress on nitrogen fixation}

High temperatures affect nitrogen fixation and symbiosis in chickpea (Rodrigues et al. 2006). Generally, high temperature reduces nodule formation, impairs nodule function and affects nodule structure (Roughley 1970; Kurdali 1996). Detrimental effect on nodule formation and nitrogen fixation efficiency of chickpea was observed in continuous warm days of $30 / 18^{\circ} \mathrm{C}$ day/night temperatures (Minchin et al. 1980). Slightly increased day temperature $\left(32.5^{\circ} \mathrm{C}\right)$ delayed nodulation, decreased total plant nitrogen fixation and longevity of the symbiotically active nodule population (Rawsthorne et al. 1985). Nodules were not formed at $>32^{\circ} \mathrm{C}$ soil temperature and recovery of nitrogenase activity failed after plant roots were exposed to $35^{\circ} \mathrm{C}$. The optimum soil temperatures for chickpea growth lie between 18 and $22^{\circ} \mathrm{C}$ for nodulation and nitrogen fixation (Dart et al. 1975). When the chickpea cultivar ILC 482 was inoculated with Rhizobium leguminosarum L., strain $\mathrm{CP} 37 \mathrm{~A}$, the initial growth rate was encouraged at $40 / 25^{\circ} \mathrm{C}$ under controlled conditions (Laurie and Stewart 1993). However, the effect of heat stress during nitrogen fixation could vary in different genotypes (Summerfield et al. 1981). Thus, further investigation of heat stress and rhizobium culture in chickpea is needed.

Most nitrogen fixation in chickpea occurs during the vegetative phase (biomass accumulation) and declines after pod filling. Most of the spring-sown chickpea is exposed to warm temperature during flowering. But in south Asia (north, central and south India), the vegetative phase is subjected to high maximum temperature of $31-33^{\circ} \mathrm{C}$ (Berger et al. 2011). From the available data, it is clear that temperature $>30^{\circ} \mathrm{C}$ has detrimental effect on nitrogen fixation. Therefore, particular consideration is needed in these regions.
The heritability of nitrogen fixation traits, under heat stress may be important to obtaining higher, more sustainable yields in hot environments. However, most research of this nature has focussed on water stress and very little has been published on heat stress. There is a need for greater knowledge of plant physiological response to nitrogen fixation by different rhizobial strains under heat stress.

\section{Adaptation mechanism}

Chickpea performance over different environments under high temperature has been covered in the previous sections. The adaptive strategies to high temperature stress are classified into the following three groups (Wery et al. 1993).

\section{Adaptation mechanisms of crop plants to high temperatures}

(1) Heat escape: plants can escape heat stress with early phenology. Though flower initiation is sensitive to rising temperature in chickpea (Toker and Canci 2006), early flowering and maturity is a heat escape mechanism (Toker et al. 2007) particularly in the Mediterranean spring-sown environments and south Indian germplasm (Berger et al. 2011).

(2) Heat avoidance: leaf reflectance, reduction of nonphotosynthetic energy intercepted by the canopy and transpiration are important physiological components of heat avoidance. Leaves play a vital role in heat avoidance by changing their orientation, transpiration rate and reflectance (Wery et al. 1993). The mechanism of heat avoidance has not been studied in chickpea and screening germplasm for heat avoidance may lead to improve productivity in heat-stressed environments.

(3) Heat tolerance: heat tolerance is linked to membrane stability, alteration of membrane lipid composition, accumulation of heat shock proteins and specific solutes (proline and glycine) particularly in pollen (Blum 1988). The role of protein functional properties (e.g. heat shock proteins) has not been studied in chickpea and their assessment may assist plant breeders in the development of heat-tolerant cultivars.

\section{Strategies to improve breeding for heat tolerance in chickpea}

Visual selection, selection for physiological traits linked to plant response to high temperature, empirical selection for yield and marker-assisted selection (MAS) are four important selection methods used to improve heat tolerance through breeding (Howarth 2005). However, the first step in the breeding process is identification of genetic diversity for economically important traits. Genetic diversity can be measured by quantifying variation in morphological characters that are targeted for selection for adaptation to heat stress. This approach has been used in south India (Krishnamurthy et al. 2011; Upadhyaya et al. 2011). Genetic diversity is also assessed using an eco-geographic approach to select chickpea 
germplasm for crossing (Berger 2007). In addition, new DNAbased fingerprinting technologies can be used to quantify the extent of diversity among potential parental lines (Lin et al. 2008).

The next step in the breeding process is selection of superior heat tolerant germplasm from the progeny of each cross. A suitable screening environment is essential. Some breeders use late planting to induce high levels of heat stress from anthesis through the grain-filling period (Krishnamurthy et al. 2011). Others use more sophisticated techniques such as field-based heat chambers or controlled environment chambers (Cottee et al. 2010). The primary consideration when choosing a screening method is relevance to the target environment. If quantitative trait loci (QTL) linked to superior heat tolerance has been identified then molecular markers associated with these QTL can be used at any time during the selection process to conserve these chromosomal regions in the progeny. While molecular markers for heat tolerance have been identified in rice (Xiao et al. 2011) and wheat (Al-Doss et al. 2010), there are currently no effective markers available in chickpea. Nevertheless, contrasting parents of chickpea for heat tolerance were crossed and used to develop recombinant inbred lines (Krishnamurthy et al. 2011), which will later be assessed for heat tolerance and QTL mapping.

\section{Conclusions and presumption for the future}

Although classification of heat responses of chickpea has been documented (Krishnamurthy et al. 2011; Upadhyaya et al. 2011), there has been little attempt to extrapolate these findings across the world's chickpea production areas. The determination of a heat response phenotype through screening is vital if the genetic control of heat tolerance in chickpea is to be understood and significant progress made through plant breeding. Clearly, the research under high temperature stress shows that early phenology is the most important mechanism and pod set the primary yield component to be considered in heat tolerance breeding. Overall, the heat stress can be studied using a holistic approach that integrates genetic and physiological characterisation of plant response to help define plant breeding targets. These combined approaches which include molecular tools and agronomic practices, will be pivotal to developing improved heat-tolerant chickpea cultivars. However, research gaps include:

- Development of simple screening methods to identify heat tolerance in chickpea genotypes relevant to the target environment,

- Determination of the physiological response of chickpea to heat stress across a range of concurrent factors such as moisture availability and evaporative demand and the underlying genetic control of these traits,

- Classification of genetic material to determine diversity groupings and establishment of genetic correlations between the traits linked to heat stress response,

- Identification of molecular markers linked to major QTL that explain a significant portion of the variation in heat tolerance.

\section{Acknowledgements}

We thank the Grains Research and Development Corporation of Australia for financial support and Professor Jeff Amthor for his insightful review of this manuscript.

\section{References}

Abbo S, Berger JD, Turner NC (2003a) Evolution of cultivated chickpea: four genetic bottlenecks limit diversity and constrain crop adaptation. Functional Plant Biology 30, 1081-1087. doi:10.1071/FP03084

Abbo S, Shtienberg D, Lichtenzveig J, Lev-Yadun S, Gopher A (2003b) The chickpea summer cropping and a new model for pulse domestication in the ancient near east. The Quarterly Review of Biology 78, 435-448. doi: $10.1086 / 378927$

Agtunong TP, Redden R, Mengge-Nang MA, Searle C, Fukai S (1992) Genotypic variation in response to high temperature at flowering in common bean (Phaseolus vulgaris L.). Animal Production Science 32, 1135-1140. doi:10.1071/EA9921135

Ahmed FE, Hall AE, DeMason DA (1992) Heat injury during floral development in cowpea (Vigna unguiculata). American Journal of Botany 79, 784-791. doi:10.2307/2444945

Al-Doss AA, Saleh M, Moustafa KA, Elshafei AA, Barakat MN (2010) Grain yield stability and molecular characterization of durum wheat genotypes under heat stress conditions. African Journal of Agricultural Research 5, 3065-3074.

Ali M (2004) Role of pulses in crop diversification in India. In 'Role of legumes in crop diversification and poverty production in Asia. Proceedings of the Joint CLAN Steering Committee Meeting'. 10-12 Nov. 2003, ICRISAT, India. (Eds CLL Gowda, S Pande) pp. 42-56. (ICRISAT: Patancheru, AP, India)

Anbessa Y, Warkentin T, Vandenberg A, Bandara M (2006) Heritability and predicted gain from selection in components of crop duration in divergent chickpea cross populations. Euphytica 152, 1-8. doi:10.1007/s10681006-9163-y

Basu PS, Ali M, Chaturvedi SK (2009) Terminal heat stress adversely affects chickpea productivity in Northern India - Strategies to improve thermotolerance in the crop under climate change. In 'ISPRS Archives XXXVIII-8/W3 Workshop Proceedings: Impact of Climate Change on Agriculture'. 23-25 February, New Delhi, India. (Eds S Panigrahy, SR Shankar, JS Parihar) pp. 189-193. (International Society for Photogrammetry and Remote Sensing, India)

Berger JD (2007) Ecogeographic and evolutionary approaches to improving adaptation of autumn-sown chickpea (Cicer arietinum L.) to terminal drought: the search for reproductive chilling tolerance. Field Crops Research 104, 112-122. doi:10.1016/j.fcr.2007.03.021

Berger JD, Milroy SP, Turner NC, Siddique KHM, Imtiaz M, Malhotra R (2011) Chickpea evolution has selected for contrasting phenological mechanisms among different habitats. Euphytica 180, 1-15. doi:10.1007/s10681-011-0391-4

Berger JD, Turner NC (2007) The ecology of chickpea. In 'Chickpea breeding and management'. (Eds SS Yadav, RJ Redden, W Chen, B Sharma) pp. 47-71. (CAB International: Wallingford, UK)

Blum A (1988) 'Plant breeding for stress environments.' (CRC Press: Boca Raton, FL)

Clarke HJ, Khan TN, Siddique KHM (2004) Pollen selection for chilling tolerance at hybridisation leads to improved chickpea cultivars. Euphytica 139, 65-74. doi:10.1007/s10681-004-2466-y

Clarke HJ, Siddique KHM (2004) Response of chickpea genotypes to low temperature stress during reproductive development. Field Crops Research 90, 323-334. doi:10.1016/j.fcr.2004.04.001

Cottee NS, Tan DKY, Bange MP, Cothren JT, Campbell LC (2010) Multilevel determination of heat tolerance in cotton (Gossypium hirsutum L.) under field conditions. Crop Science 50, 2553-2564. doi:10.2135/ cropsci2010.03.0182 
Covell S, Ellis RH, Roberts EH, Summerfield RJ (1986) The influence of temperature on seed germination rate in grain legumes I. A comparison of chickpea, lentil, soybean, and cowpea at constant temperatures. Journal of Experimental Botany 37, 705-715. doi:10.1093/jxb/37.5.705

Craufurd PQ, Wheeler TR (2009) Climate change and the flowering time of annual crops. Journal of Experimental Botany 60, 2529-2539. doi:10.1093/jxb/erp196

Dart PJ, Islam R, Eaglesham A (1975) The root nodule symbiosis of chickpea and pigeonpea. In 'Proceedings, International Workshop in Grain Legumes'. 13-16 January, ICRISAT, Patancheru, AP, India. pp. 63-83. (ICRISAT: Patancheru, India)

Davies SL, Turner NC, Siddique KHM, Plummer JA, Leport A (1999) Seed growth of desi and kabuli chickpea (Cicer arietinum L.) in a short season Mediterranean type environment. Animal Production Science 39, 181-188. doi:10.1071/EA98134

Devasirvatham V, Tan DKY, Trethowan RM, Gaur PM, Mallikarjuna N (2010) Impact of high temperature on the reproductive stage of chickpea. In 'Food security from sustainable agriculture. Proceedings of the 15th Australian Society of Agronomy Conference'. 15-18 November 2010, Lincoln, New Zealand. (Eds H Dove, RA Culvenor) Available at: www. regional.org,au/au/asa/2010/index.htm

Dua RP (2001) Genotypic variations for low and high temperature tolerance in gram (Cicer arietinum). Indian Journal of Agricultural Sciences 71, $561-566$.

Egli DB, TeKrony DM, Spears JF (2005) Effect of high temperature stress during different stages of seed development in soybean (Glycine max L. Merrill). Seed Technology 27, 177-189.

Ellis RH, Covell S, Roberts EH, Summerfield RJ (1986) The influence of temperature on seed germination rate in grain legumes. Journal of Experimental Botany 37, 1503-1515. doi:10.1093/jxb/37.10.1503

Erskine W, Hussain A, Tahir M, Bahksh A, Ellis RH, Summerfield RJ, Roberts EH (1994) Field evaluation of a model of photothermal flowering responses in a world lentil collection. Theoretical and Applied Genetics 88, 423-428. doi:10.1007/BF00223655

Evans LT (1993) Processes, genes and yield potential. In 'International crop science I'. (Eds DR Buxton, R Shibles, RA Forsberg, BL Blad, KH Asay, GM Paulsen, RF Wilson) pp. 687-696. (Crop Science Society of America Publishing: Madison, WI)

Gaur PM, Pande S, Sharma HC, Gowda CLL, Sharma KK, Crouch JH, Vadez V (2007) Genetic enhancement of stress tolerance in chickpea: present status and future prospects. In 'Crop production stress environments: genetic and management options'. (Eds DP Singh, VS Tomar, RK Behl, SD Upadhyaya, MS Bhale, D Khare) pp. 85-94. (AGROBIOS International Publishing: Jodhpur, India)

Grace J (1988) Temperature as a determinant of plant productivity. In 'Plants and temperature'. (Eds SP Long, FI Woodward) pp. 91-108. (The Society of Experimental Biology Publishing: Cambridge, UK)

Gross Y, Kigel J (1994) Differential sensitivity to high temperature of stages in the reproductive development in common bean (Phaseolus vulgaris L.). Field Crops Research 36, 201-212. doi:10.1016/03784290(94)90112-0

Hall AE (1992) Breeding for heat tolerance. Plant Breeding Reviews 10, $129-168$.

Hendrix JE (2001) Production related to assimilate transport and partitioning. In 'Handbook of plant and crop physiology'. (Ed. M Pessarakli) pp. 421-448. (CRC Press: Boca Raton, FL)

Howarth CJ (2005) Genetic improvements of tolerance to high temperature. In 'Abiotic stresses - plant resistance through breeding and molecular approaches'. (Eds M Ashraf, PJC Harris) pp. 277-300. (The Haworth Press: New York)

ICRISAT (International Crops Research Institute for the Semi-Arid Tropics) (1979) Chickpea-Physiology. In 'Annual Report 1978-79'. Patancheru, AP, India. pp. 125-126. (ICRISAT: Patancheru, India)
Iliadis C (1990) Chickpea production in Greece. Options Méditerranéennes, Série Séminaires 9, 141-143.

Iwahori S (1965) High temperature injuries in tomato IV. Development of normal flower buds and morphological abnormalities of flower buds treated with high temperature. Journal of the Japanese Society of Horticultural Science 34, 33-41. doi:10.2503/jjshs.34.33

Jaiwal PK, Mehta K (1983) The thermo sensitivity of pollen behaviour in Cicer arietinum L. International Chickpea Newsletter 9, 15.

Kakani VG, Prasad PVV, Craufurd PQ, Wheeler TR (2002) Response of in vitro pollen germination and pollen tube growth of groundnut (Arachis hypogaea L.) genotypes to temperature. Plant, Cell \& Environment 25, 1651-1661. doi:10.1046/j.1365-3040.2002.00943.x

Kalra N, Chakraborty D, Sharma A, Rai HK, Jolly M, Chander S, Kumar PR, Bhadraray S, Barman D, Mittal RB, Lal M, Sehgal M (2008) Effect of temperature on yield of some winter crops in northwest India. Current Science 94, 82-88.

Khanna-Chopra R, Sinha SK (1987) Chickpea: physiological aspects of growth and yield. In 'The chickpea'. (Eds MC Saxena, KB Singh) pp. 63-189. (CAB International: Wallingford, UK)

Konsens I, Ofir M, Kigel J (1991) The effect of temperature on the production and abscission of flowers and pods in snap bean (Phaseolus vulgaris L.). Annals of Botany 67, 391-399.

Koti S, Reddy KR, Reddy VR, Kakani VG, Zhao D (2005) Interactive effects of carbon dioxide, temperature, and ultraviolet-B radiation on soybean (Glycine $\max$ L.) flower and pollen morphology, pollen production, germination, and tube lengths. Journal of Experimental Botany 56, 725-736. doi:10.1093/jxb/eri044

Krishnamurthy L, Gaur PM, Basu PS, Chaturvedi SK, Tripathi S, Vadez V, Rathore A, Varshney RK, Gowda CLL (2011) Large genetic variation for heat tolerance in the reference collection of chickpea (Cicer arietinum L.) germplasm. Plant Genetic Resources 9, 59-69. doi:10.1017/S1479262110000407

Kumar J, Abbo S (2001) Genetics of flowering time in chickpea and its bearing on productivity in semi-arid environments. Advances in Agronomy 72, 107-138. doi:10.1016/S0065-2113(01)72012-3

Kurdali F (1996) Nitrogen and phosphorus assimilation, mobilization and partitioning in rainfed chickpea (Cicer arietinum L.). Field Crops Research 47, 81-92. doi:10.1016/0378-4290(96)00034-2

Laurie S, Stewart GR (1993) Effects of nitrogen supply and high temperature on the growth and physiology of chickpea. Plant, Cell \& Environment 16, 609-621. doi:10.1111/j.1365-3040.1993.tb00479.x

Leport L, Turner NC, French RJ, Barr MD, Duda R, Davies SL, Tennant D, Siddique KHM (1999) Physiological response of chickpea genotypes to terminal drought in a Mediterranean-type environment. European Journal of Agronomy 11, 279-291. doi:10.1016/S1161-0301(99) 00039-8

Lin R, Yang H, Khan TN, Siddique KHM, Yan G (2008) Characterisation of genetic diversity and DNA fingerprinting of Australian chickpea (Cicer arietinum L.) cultivars using MFLP markers. Crop \& Pasture Science 59, 707-713. doi:10.1071/AR07401

Liu PH, Gan Y, Warkentin T, McDonald (2003) Morphological plasticity of chickpea in a semi-arid environment. Crop Science 43, 426-429. doi: $10.2135 /$ cropsci2003.0426

McDonald GK, Paulsen GM (1997) High temperature effects on photosynthesis and water relations of grain legumes. Plant and Soil 196, 47-58. doi:10.1023/A:1004249200050

Minchin FR, Summerfield RJ, Hadley P, Roberts EH (1980) Growth, longevity and nodulation of roots in relation to seed yield in chickpea (Cicer arietinum L.). Experimental Agriculture 16, 241-261. doi:10.1017/S0014479700010991

Moore K, Knights T (2009) Aschochyta blight in 2008 northern NSW chickpea crop and advice for 2009. Pulse Tech-Notes Autumn 2009, Vic. Australia. 
Nakano H, Kobayashi M, Terauchi T (1998) Sensitive stages to heat stress in pod setting of common bean (Phaseolus vulgaris L.). Japanese Journal of Tropical Agriculture 42, 72-84.

Nakano H, Momonoki T, Miyashige T, Otsuka H, Hanada T, Sugimoto A, Nakagawa H, Matsuoka M, Terauchi T, Kobayashi M, Oshiro M, Yasuda K, Vanichwattanarumruk N, Chotechuen S, Boonmalison D (1997) 'Haibushi', a new variety of snap bean tolerant to heat stress. Japan International Research Center for Agricultural Sciences Journal 5, 1-12.

Nayyar H, Bains T, Kumar S (2005) Low temperature induced floral abortion in chickpea: relationship to abscisic acid and cryoprotectants in reproductive organs. Environmental and Experimental Botany 53, 39-47. doi:10.1016/j.envexpbot.2004.02.011

Ormrod DP, Woolley CJ, Eaton GW, Stobbe EH (1967) Effect of temperature on embryo sac development in Phaseolus vulgaris L. Canadian Journal of Botany 45, 948-950. doi:10.1139/b67-097

Ozdemir S, Karadavut U (2003) Comparison of the performance of autumn and spring of chickpeas in a temperate region. Turkish Journal of Agriculture and Forestry 27, 345-352.

Patrick JW, Stoddard FL (2010) Physiology of flowering and grain filling in faba bean. Field Crops Research 115, 234-242. doi:10.1016/ j.fcr.2009.06.005

Porch TG, Jahn M (2001) Effects of high-temperature stress on microsporogenesis in heat-sensitive and heat-tolerant genotypes of Phaseolus vulgaris. Plant, Cell \& Environment 24, 723-731. doi:10.1046/j.1365-3040.2001.00716.x

Rawsthorne S, Hadley P, Roberts EH, Summerfield RJ (1985) Effects of supplemental nitrate and thermal regime on the nitrogen nutrition of chickpea (Cicer arietinum L.) П: Symbiotic development and nitrogen assimilation. Plant and Soil 83, 279-293. doi:10.1007/BF02184299

Rodrigues CS, Laranjo M, Oliveira S (2006) Effect of heat and pH stress in the growth of chickpea Mesorhizobia. Current Microbiology 53, 1-7. doi: $10.1007 / \mathrm{s} 00284-005-4515-8$

Roughley RJ (1970) The influence of root temperature, Rhizobium strain and host selection on the structure and nitrogen-fixing efficiency of the root nodules of Trifolium subterraneum. Annals of Botany 34, 631-646.

Saxena MC (1987) Agronomy of chickpea. In 'The chickpea'. (Eds MC Saxena, KB Singh) pp. 207-232. (CAB International: Wallingford, UK)

Sharma KD, Pannu RK, Behl RK (2005) Effect of early and terminal heat stress on biomass portioning, chlorophyll stability and yield of different wheat genotypes. In 'Proceedings of the International Conference on Sustainable Crop Production in Stress Environments: Management and Genetic Options'. 9-12 Feb. (Ed. KB Singh) pp. 87-194. (Jawaharlal Krishi Vishwa Vidyalaya: Jabalpur, MP, India)

Singh DP, Peters DB, Singh P, Singh M (1987) Diurnal patterns of canopy photosynthesis, evapotranspiration and water use efficiency in chickpea (Cicer arietinum L.) under field conditions. Photosynthesis Research 11, 61-69. doi:10.1007/BF00117674

Singh DP, Rawson HM, Turner MC (1982) Effect of radiation, temperature and humidity in photosynthesis, transpiration and water use efficiency of chickpea (Cicer arietinum L.). Indian Journal of Plant Physiology 25, $32-39$.

Singh KB (1997) Chickpea (Cicer arietinum L.). Field Crops Research 53 , 161-170. doi:10.1016/S0378-4290(97)00029-4

Singh KB, Malhotra RS, Halila MH, Knights EJ, Verma MM (1994) Current status and future strategy in breeding chickpea for resistance to biotic and abiotic stresses. Euphytica 73, 137-149. doi:10.1007/BF00027190

Singh NH, Dhaliwal GS (1972) Effect of soil temperature on seedling emergence in different crops. Plant and Soil 37, 441-444. doi:10.1007/ BF02139989

Sinha SK (1977) 'Food legumes: distribution, adaptability and biology of yield. FAO Plant Production and Protection Paper No. 3.' (FAO: Rome, Italy)
Sivakumar MVK, Singh P (1987) Response of chickpea cultivars to water stress in semi-arid environment. Experimental Agriculture 23, 53-61. doi: $10.1017 /$ S0014479700001125

Sivaprasad B, Sundrasarma KS (1987) Effect of temperature on seedling growth under impeding conditions. Plant and Soil 101, 145-148. doi:10.1007/BF02371044

Srinivasan A, Saxena NP, Johansen C (1999) Cold tolerance during early reproductive growth of chickpea (Cicer arietinum L.): genetic variation in gamete development and function. Field Crops Research 60, 209-222. doi:10.1016/S0378-4290(98)00126-9

Srinivasan A, Takeda H, Senboku T (1996) Heat tolerance in food legumes as evaluated by cell membrane thermostability and chlorophyll fluorescence techniques. Euphytica 88, 35-45. doi:10.1007/BF00029263

Stoddard FL, Balko C, Erskine W, Khan HR, Link W, Sarker A (2006) Screening techniques and source of resistance to abiotic stresses in coolseason food legumes. Euphytica 147, 167-186. doi:10.1007/s10681-0064723-8

Summerfield RJ, Minchin FR, Roberts EH, Hadley P (1980) The effects of photoperiod and air temperature on growth and yield of chickpea (Cicer arietinum L.). In 'Proceedings of International Workshop on Chickpea Improvement'. 28 Feb. -2 March 1979, The International Crops Research Institute for the Semi-Arid Tropics, Patancheru, AP, India. (Eds JM Green, YL Nene, JB Smithson) pp. 121 -149. (ICRISAT Publishing: Hyderabad, India)

Summerfield RJ, Hadley P, Roberts EH, Minchin FR, Rawsthrone S (1984) Sensitivity of chickpea (Cicer arietinum $\mathrm{L}$.) to hot temperatures during the reproductive period. Experimental Agriculture 20, 77-93. doi:10.1017/ S0014479700017610

Summerfield RJ, Minchin FR, Roberts EH, Hadley P (1981) Adaptation to contrasting aerial environments in chickpea (Cicer arietinum $\mathrm{L}$.). Tropical Agriculture 58, 97-113.

Summerfield RJ, Roberts EH, Erskine W, Ellis RH (1985) Effect of temperature and photoperiod on flowering in lentils (Lens culinaris Medic.). Annals of Botany 56, 659-671.

Summerfield RJ, Virmani SM, Roberts EH, Ellis RH (1990) Adaption of chickpea to agroclimatic constraints. In 'Chickpea in the nineties. Proceedings of the Second International Workshop on Chickpea Improvement'. 4-8 December 1989. ICRISAT Center, Hyderabad, AP, India. (Eds HA van Rheenen, MC Saxena) pp. 50-61. (ICRISAT Publishing: Hyderabad, India)

Talwar HS, Yanagihara S (1999) 'Physiological basis of heat tolerance during flowering and pod setting stages in groundnut (Arachis hypogaea L.).' JIRCAS Workshop Report No. 14. (JJRCAS: Tsubuka, Japan)

Toker C, Canci H (2006) Selection for drought and heat resistance in chickpea under terminal drought conditions. In 'Food legumes for nutritional security and sustainable agriculture. 4th International Food Legumes Research Conference'. (Ed. MC Kharkwal) pp. 18-22. (Indian Agricultural Research Institute: New Delhi)

Toker C, Llunch C, Tejera NA, Serraj R, Siddique KHM (2007) Abiotic stresses. In 'Chickpea breeding and management'. (Eds SS Yadav, RJ Redden, W Chen, B Sharma) pp. 474-496. (CAB International: Wallingford, UK)

Tongden C, Basant M, Chakraborty U (2006) Screening of thermotolerant cultivars of chickpea using cell membrane stability test and biochemical markers. Journal of Hill Research 19, 52-58.

Upadhyaya HD, Dronavalli N, Gowda CLL, Singh S (2011) Identification and evaluation of chickpea germplasm for tolerance to heat stress. Crop Science 51, 2079-2094. doi:10.2135/cropsci2011.01.0018

van der Maesen LJG (1972) 'A monograph of the genus, with special references to the chickpea (Cicer arietinum L.) its ecology and cultivation.' (Mendelingen Landbouwhoge School: Wageningen, The Netherlands) 
Vara Prasad PV, Craufurd PQ, Kakani VG, Wheeler TR, Boote KJ (2001) Influence of high temperature during pre- and post-anthesis stages of floral development on fruit set and pollen germination in peanut. Functional Plant Biology 28, 233-240. doi:10.1071/PP00127

Vara Prasad PV, Craufurd PQ, Summerfield RJ (1999) Sensitivity of peanut to timing of heat stress during reproductive development. Crop Science 39, 1352-1359. doi:10.2135/cropsci1999.3951352x

Wang J, Gan YT, Clarke F, McDonald CL (2006) Response of chickpea yield to high temperature stress during reproductive development. Crop Science 46, 2171-2178. doi:10.2135/cropsci2006.02.0092

Warrag MOA, Hall AE (1983) Reproductive responses of cowpea to heat stress: genotypic differences in tolerance to heat at flowering. Crop Science 23, 1088-1092. doi:10.2135/cropsci1983.0011183X0023000 $60016 \mathrm{x}$

Warrag MOA, Hall AE (1984) Reproductive responses of cowpea (Vigna unguiculata L. Walp.) to heat stress - II Responses to night air temperature. Field Crops Research 8, 17-33. doi:10.1016/0378-4290(84) 90049-2

Weerakoon WMW, Maruyama A, Ohba K (2008) Impact of humidity on temperature-induced grain sterility in rice (Oryza sativa L). Journal of Agronomy \& Crop Science 194, 135-140. doi:10.1111/j.1439-037X. 2008.00293.x
Wery J, Silim SN, Knights EJ, Malhotra RS, Cousin R (1994) Screening techniques and sources of tolerance to extremes of moisture and air temperature in cool season food legumes. Euphytica 73, 73-83. doi:10.1007/BF00027184

Wery J, Turc O, Lecoeur J (1993) Mechanism of resistance to cold, heat and drought in cool-season legumes, with special reference to chickpea and pea. In 'Food legumes'. (Eds KB Singh, MC Saxena) pp. 271-291. (Wiley Publishing: Chichester, UK)

Xiao YH, Pan Y, Luo LH, Deng HB, Zhang GL, Tang WB, Chen LY (2011) Quantitative trait loci associated with pollen fertility under high temperature stress at flowering stage in rice (Oryza sativa). Rice Science 18, 204-209. doi:10.1016/S1672-6308(11)60028-0

Zinn KE, Tunc-Odemir M, Harper JF (2010) Temperature stress and plant sexual reproduction: uncovering the weakest links. Journal of Experimental Botany 61, 1959-1968. doi:10.1093/jxb/erq053 